\title{
Jármúipari és Térgazdasági Kutatócsoport a Széchenyi István Egyetemen
}

\section{Research Group for Spatial Economics and Automotive Industry at Széchenyi István University}

\author{
RECHNITZER JÁNOS, SMAHÓ MELINDA
}

A Széchenyi István Egyetemen, illetve annak jogelődjénél 1991-ben kezdődött meg a regionális tudomány oktatása. 1993-ban az akkori közgazdászképzés keretén belül létrejött a területfejlesztési szakirány, s így az üzemgazdászképzésben sikerült meghonosítani a területi folyamatok elemzésére és fejlesztésére vonatkozó ismeretek oktatását. A bolognai rendszerű képzés keretében, 2006-tól a közszolgálati szakon indította az egyetem a területfejlesztési szakirányt, majd 2008-tól sikeresen akkreditáltatta a regionális és környezeti gazdaságtan mesterszakot. 2011-től a közszolgálati alapszakon a korábbi szakirányt a helyi kormányzás irányába módosította, ezzel részben megalapozta a mesterképzést, részben pedig az igényekhez igazította az oktatást.

A regionális tudományi kutatóbázis, amelyet az MTA RKK Nyugat-magyarországi Tudományos Intézete jelentett, kiváló alapot adott arra, hogy 2003-ban akkreditálásra kerüljön, majd 2004 februárjában beinduljon a Multidiszciplináris Társadalomtudományi Doktori Iskola, ahol a regionális tudomány, a közgazdaságtudomány és a jogtudomány együtt szerepelt a programban. A doktori iskola jogi szárnya önállósult, így 2008-tól már Regionális és Gazdaságtudományi Doktori Iskola keretében folyik a képzés. Az eddigi nyolc évfolyam 177 beiratkozott doktoranduszából 30 fó tudta sikeresen megvédeni a disszertációját (17\%), s közülük tízen viselhetik a regionális tudomány doktora fokozatot.

A képzés rendszerének teljes vertikumban történő kialakítása, s annak közel két évtizeden át történő folyamatos müvelése egyértelműen megteremtette a szervezett regionális tudományi kutatások alapját, amihez az MTA RKK Nyugat-magyarországi Tudományos Intézetének alkotó közremüködése, szellemi erőforrásainak, tudományos kapcsolatainak hasznosítása is nagymértékben hozzájárult.

Az oktatás mellett a hely szelleme (genius loci) kettős értelemben befolyásolja a kutatás irányait. Az első maga a város, Győr. A 19. század végén indult meg a közlekedési eszközök gyártása, először a vagon-, majd a gépjármügyár- 
tás. A város vált a hazai jármügyártás egyik központjává, hiszen a Rába Vagon- és Gépgyár, s annak jogelődei ebben a szektorban mindig is az európai élvonalat jelentették. A jármügyártási kultúra és infrastruktúrája volt az alapja annak, hogy 1993-ban az Audi AG leányvállalata, az Audi Hungária Motor Kft. megtelepedett a városban, és 2010-ben már 1648000 motort és 38500 jármüvet állított elő a 6138 munkatársával. A folyamatban lévő, közel 900 millió euró beruházással 2013-ban a jelenlegi motorszám mellett 125 ezer autót kívánnak gyártani, s a foglalkoztatottak számát 8000 főre szándékoznak növelni. Győr nemcsak Kelet-Közép-Európa vezető jármügyártó központja lett, hanem a prémiumautók vonatkozásában európai jelentőségűvé is vált.

A hely szellemének másik dimenzióját a Széchenyi István Egyetem testesíti meg. A ma már egyetemi rangú intézmény a jármüipari termelési bázisra települt 1970-ben, s napjainkra 52 alapszakon, 16 mesterszakon és három doktori iskolában együttesen 12 ezer hallgatóval rendelkezik. Az egyetem az elmúlt három évben teljesen megújult, hiszen közel 12 milliárd Ft értékben hajtott végre fejlesztést, ami megújította az infrastruktúrát, az oktatási és kutatási eszközállományt, valamint a képzési rendszer tartalmi elemeit is.

A városban koncentrált járműipari adottságok, az egyetem új szellemisége és az akadémiai kutatóintézet által képviselt regionális tudományi profil együttesen nagyszerű alapot teremtettek arra, hogy az egyetemen belül új kutatási egység jöjjön létre. 2010 szeptemberében alakult meg a Járműipari és Térgazdasági Kutatócsoport, amelynek alapját a Széchenyi István Egyetem és a Pannon Egyetem konzorciuma által elnyert TAMOP-4.2.1/B-09/1/KONV-2010-0003 Mobilitás és környezet: jármüipari, energetikai és környezeti kutatások a közép-és nyugat-dunántúli régióban címü projektnek A jármüipar gazdasági szerepe a közép- és nyugat-dunántúli régióban címü alprojektje jelentette és jelenti napjainkban is. A „JÁTÉK” névre keresztelt kutatócsoport Rechnitzer János és Smahó Melinda vezetése mellett, 3 PhD-hallgató (Kollár Katalin, Füzi Anita, Tóth Tamás) és 2 ügyvivő-szakértő (Pató Melinda, Szabados Eszter) bevonásával múködik. Az alprojekttel kapcsolatos kutatómunkában 24 oktató, 10 PhD-hallgató és 6 egyetemi hallgató vesz részt.

Az alprojekt célja azoknak a gazdasági és térségi összefüggéseknek a bemutatása, amelyek a két régióban befolyásolják a jármüipar, azon belül a személygépkocsi-gyártás fejlődését, illetve érzékeltetik az iparág hatását a két régió jövőbeli fejlődésének alakulására, annak irányaira. Korábbi kutatások megerősítették, hogy a közép- és nyugat-dunántúli régióban koncentrálódnak a hazai jármügyártás, s azon belül az autóipar legnagyobb gyártókapacitásai, továbbá a beszállítói hálózat is jelentősnek tekinthető. A két régió ugyanakkor egy formálódó kelet-közép-európai autóipari versenytérben található, így lényeges, hogy a magyar területi egységeket, azok centrumait pozicionálni tudjuk ebben az ágazati specializációt is egyre látványosabban mutató nagytérségben.

Az alprojekt két részre tagolódik: a „Versenyképesség, Kelet-Közép-Európa” nevet viselő K+F-projekt célja a kelet-közép-európai térség gépjármügyártásának átfogó bemutatása, ezzel a magyar régiók nagytérségi versenyterének értékelése. A 
Győr-Esztergom-Szentgotthárd háromszög 300 kilométeres körzetében több mint 3 millió motor gyártása és 500-600 ezer jármü összeszerelése folyik. A 2010es évek elejére tehát létrejött egy kelet-közép-európai autógyártási nagyrégió, több autógyárral és temérdek beszállítóval. Egyik célunk a jármügyártási kapacitások feltérképezése a kelet-közép-európai térségben (Németország, Ausztria, Szlovénia, Csehország, Szlovákia, Lengyelország, Magyarország, Románia), továbbá a járműgyártó egységek fejlesztési irányainak, termékszerkezetének és termelési kapacitásainak megismerése. Vizsgáljuk a jármügyártás helyi (lokális) és regionális gazdasági-társadalmi hatásait, valamint a további fejlesztés lehetőségeit.

Kidolgozzuk a kelet-közép-európai nagytérség NUTS 2-es régióinak és járműgyártási központjainak versenyképesség-elemzését, amelynek során figyelmet fordítunk a jármüipar (autóipar) mint ágazat specifikumaira és ezek mérésére (a foglalkoztatottak száma, az iparághoz kapcsolódó innovációs központok, ipari parkok, képzőintézmények mutatói s mindazok a tényezők, amelyek a járműgyártás szempontjából fontosak). Ennek alapján hasonlítjuk össze a jármüipari központokat és régióikat. A versenyképességi elemzéshez kapcsolódik a járműipar (autóipar) telepitési tényezőinek számbavétele az egyes régiókban és járműipari központokban. Ennek keretében elemezzük az országos szintü, a regionális és a helyi gazdasági ösztönzési, támogatási és intézményrendszereket mint a piaci környezetet alakító faktorokat, továbbá a jármüipar térbeli elhelyezkedését, koncentrálódását meghatározó tényezőket (klaszteresedés). Végül kialakíthatjuk a jármügyártásra épülő fejlesztési stratégia főbb csomópontjait: olyan ajánlásokat kívánunk megfogalmazni, amelyek a középés nyugat-dunántúli régiók autógyártásra irányuló fejlesztési stratégiáinak kidolgozásához, valamint a 2014-ben induló tervezési időszak megalapozásához egyaránt felhasználhatók.

A másik K+F-projekt „A közép-és nyugat-dunántúli régióban található jármüipari beszállitói hálózat elemzésével" foglalkozik, célja a két hazai régióban található, döntően a jármü-/autógyártáshoz kapcsolódó vállalkozások számbavétele, az innovációs és fejlesztési körülmények feltárása, továbbá üzleti és menedzsmentrendszereik bemutatása. Ennek során számba vesszük a jármügyártáshoz, azon belül fóként az autógyártáshoz kapcsolódó termelési kapacitásokat (vállalkozásokat) és általános gazdasági jellemzőiket (termelés, foglalkoztatás, telephelyek, főbb telepítési tényezők). Értékeljük ezen ipari szektorok szerepét a két régió gazdaságának egészében, megadva egyrészt azokat a tényezőket, amelyek a szektor fogadása szempontjából kedvezőek, másrészt azokat, amelyek vonatkozásában - a telepítési és üzleti általános értékelés alapján - további fejlesztések kívánatosak.

Kérdőíves felméréssel és mélyinterjúk segítségével vizsgáljuk a beszállító vállalkozások innovációs aktivitását, megújítási képességét, keresve azokat a belső és külső tényezőket, amelyek termékfejlesztésüket és piaci helyzetüket alakítják. Elemezzük az adott település, térség, régió gazdaságába (beszerzések, kooperációs kapcsolatok) való beépültségüket, valamint a településen, 
térségben, régióban rendelkezésre álló gazdasági kapacitásokkal és fejlesztési intézményrendszerekkel (egyetem, kutatási szervezetek, innovációs szolgáltatások, szakemberállomány stb.) való együttműködésüket, illetve együttműködési igényeiket. Értékeljük a jármű-/autóiparhoz kapcsolódó vállalkozások hálózatosodásának eddigi folyamatait és jövőbeli lehetőségeit.

A kutatás célja, hogy feltérképezzük a jármü-/autóipari beszállító vállalkozások piaci és üzleti miliőjét, értékeljük a vállalatirányítás és -szervezés rendszereit, ajánlásokat fogalmazzunk meg a szervezet és a kapcsolatok fejlesztésére. Az eredmények alapján fejlesztési irányokat dolgozunk ki a vállalkozások hatékonyabb múködésének és piaci környezetének alakítására és az innovációs aktivitás fejlesztésére.

A 2010 őszén indult kutatás eljutott az eredmények kiértékelésének, a kutatási jelentések megírásának szakaszába. A „Versenyképesség, Kelet-Közép-Euró$p a$ " blokkban az elemzésbe bevont nyolc ország esetében egy NUTS 2 szintü, a visegrádi országok esetében pedig egy NUTS 3 szintü adatbázist állítottunk össze. „A közép- és nyugat-dunántúli régióban található jármüipari beszállítói hálózat elemzése" blokkban egy 118 elemü, kérdőíves felmérésből származó minta, továbbá 45 mélyinterjú szolgál az értékelés alapjául. A két K+F-projekt eredményeit 2012 tavaszáig egy-egy önálló tanulmánykötetben tervezzük megjelentetni.

A JÁTÉK elindult, működésének kereteit 2012. április végéig a már említett TAMOP-projekt biztosítja. Ugyanakkor már formálódik a jövő: 2011 májusában a Széchenyi István Egyetemen megalakult a Járműipari Kutató Központ, amelynek 6. kutatási főiránya a jármüipar gazdasági és társadalmi összefüggéseinek elemzésével foglalkozik, és egy jelentős európai uniós K+F-projektre pályázik. A kutatócsoport - a jelenlegi projekt befejezése után - ennek keretében kívánja folytatni a tevékenységét.

\section{Köszönetnyilvánítás}

„TAMOP-4.2.1/B-09/1/KONV-2010-0003: Mobilitás és környezet: járműipari, energetikai és környezeti kutatások a közép- és nyugat-dunántúli régióban. A projekt a magyar állam és az Európai Unió támogatásával, az Európai Szociális Alap társfinanszírozásával valósul meg." 